\author{
Aleksander Ostapiuk \\ Uniwersytet Ekonomiczny we Wrocławiu \\ e-mail: aleksander.ostapiuk@ue.wroc.pl
}

\title{
MATEMATYZACJA EKONOMII - GRZECH PIERWORODNY? WIELOASPEKTOWA ANALIZA WPLYWU I PRZYCZYN MATHEMATISATION OF ECONOMICS - ORIGINAL SIN? MULTIFACETED ANALYSIS OF INFLUENCE AND CAUSES
}

DOI: $10.15611 / \mathrm{e} 21.2017 .1 .06$

JEL Classification: A12, B10, C10

\begin{abstract}
Streszczenie: Celem artykułu jest wskazanie, w jaki sposób matematyka wpłynęła na ekonomię, a także krytyczna analiza tego procesu. Artykuł rozpoczęto od zbadania wpływu matematyki na inne nauki, począwszy od czasów starożytnych Greków. Kartezjusza zaprezentowano jako osobę, za sprawą której matematyka stała się królową nauk. Następnie przeanalizowano zwiększenie wpływu matematyki na życie intelektualne. Pozytywizm jest ujęto jako asumpt do rewolucji marginalistycznej. Od tego momentu matematyka miała coraz większy wpływ na ekonomię. Moment kulminacyjny w tej relacji przypadł na okres po II wojnie światowej - w tekście ten wpływ przedstawiono w różnych ujęciach. W tekście podjęto również próbę udzielenia odpowiedzi na pytanie, dlaczego mariaż ekonomii i matematyki jest możliwy i dlaczego ekonomia neoklasyczna tak chętnie na niego przystała. W artykule omówiono negatywne konsekwencje tego połączenia, z kryzysem z 2008 roku włącznie, a także wysunięto propozycję, by ekonomia korzystała z matematyki jako narzędzia, a nie traktowała jej jako celu samego w sobie.
\end{abstract}

Słowa kluczowe: ekonomia neoklasyczna, matematyzacja, homo oeconomicus, redukcjonizm, formalizm.

Summary: The aim of this article is to take a broad look at how mathematics has influenced economics and to critically analyse this process. The article begins with an analysis of the impact of mathematics on other sciences since the days of the ancient Greeks. Descartes is presented as a person who made that mathematics became a real queen of the sciences. Then the increase of the influence of mathematics on intellectual life is shown. Positivism is presented as a starting point which created a suitable atmosphere to begin the marginal revolution. From that moment mathematics has had an increasing impact on economics. The climax fell after World War II and the article shows that influence from different views. This article tries to find an answer why this mirage of economics and mathematics is possible and why neoclassical economics accepted it so willingly. The article also presents the negative consequences of this connection, with the crisis of the 2008 inclusive. At the end of the article the suggestion is proposed that economics should use mathematics as a tool, and not treat it as an end in itself.

Keyword: neoclassical economics, mathematisation, homo oeconomicus, reductionism, formalism. 


\section{Wstęp}

W powszechnej opinii ekonomia uważana jest za naukę precyzyjną i matematyczną, naukę, która różni się od innych nauk społecznych, takich jak: psychologia, socjologia czy politologia. Celem artykułu jest pokazanie, jak przebiegał proces matematyzacji ekonomii i jak duży ma to wpływ na dzisiejszą ekonomię. Od wielu lat narasta krytyka neoklasycznej ekonomii (jej modeli i uproszczenia pojmowania zarówno człowieka, jak i rzeczywistości). W artykule przedstawiono kamienie milowe w procesie matematyzacji ekonomii, bardzo szeroko analizując historię idei. Taka obserwacja jest niezwykle ważna, nie tylko ze względów historycznych. Krytyczna analiza przyczyn matematyzacji ekonomii może pomóc ekonomistom zrozumieć, że matematyka jest potrzebna ekonomii, ale tylko jako narzędzie, a ekonomia nadal pozostaje nauką społeczną.

\section{Matematyka. Królowa nauk}

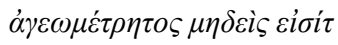

Powyższy cytat pochodzi z greki i po przetłumaczeniu brzmi następująco: „Niech nie wchodzi nikt nieobeznany z geometrią" (czyli z matematyką). Był to napis umieszczony nad wejściem do akademii Platona, który uważał, że bez zrozumienia matematyki nie powinno się zaczynać nauki filozofii. Platon nie był w swoich opiniach osamotniony. W jego czasach matematyka w Grecji była bardzo poważana, głównie za sprawą pitagorejczyków, którzy uważali matematykę za ważne filozoficzne narzędzie, potrzebne do poznawania świata, a najważniejszym elementem wszechświata była dla nich liczba. Dla pitagorejczyków, którzy zajmowali się geometrią, niezwykle istotne były proporcje. Za ich pomocą wyliczali ruchy słońca i innych planet, a także określali optymalną wielkość społeczności czy geometryczny kształt miasta. Mimo tak szerokiego wykorzystania matematyki, w niewielkim stopniu była ona używana w ekonomii, co wynikało z tego, że nie cieszyła się ona wówczas poważaniem wśród myślicieli. Sokrates, Platon i Arystoteles nie rozumieli procesów rozkwitających powiązań handlowych między greckimi miastami. Pisząc o gospodarce, bardziej polegali na swoich instynktach aniżeli na obserwacji i rozumie, pogardzając pracą rzemieślników czy handlowców [De Soto 2010]. Upadkowi Grecji towarzyszyło tysiącletnie zaniedbanie matematyki na kontynencie europejskim, które zakończyło się wraz z Kartezjuszem².

To właśnie Kartezjusz w XVII wieku przywrócił znaczenie matematyce, co więcej, uznał ją za najważniejszą z nauk. To francuskiemu filozofowi zawdzięczamy dzisiejszy kształt filozofii, która oparta jest na rozumie, a nie emocjach. René

${ }^{1}$ Warto zwrócić uwagę na bujny rozkwit matematyki arabskiej, który rozpoczął się w VIII wieku, a zakończył się w wieku XV. 
Descartes miał ogromny wpływ na rozwój nauki, ponieważ uważał, że rozumowanie naukowe powinno być przedstawiane za pomocą argumentów i dedukcji. Niezwykle ważna jest rola matematyki, ponieważ zaczęła być ona, razem z mechaniką, postrzegana jako uosobienie rozumu, racjonalności i prawdy idealnej. Matematyka stała się językiem, który należało stosować do wyrażenia prawdy naukowej czy przedstawienia jakiegoś modelu lub reguły.

Minęło sporo czasu, zanim matematyka w ekonomii zaczęła wyglądać tak jak dzisiaj. Do czasu rewolucji marginalistycznej klasycy ekonomii praktycznie nie korzystali ze wzorów ani z matematycznych modeli. Najlepszym przykładem ,przedmatematycznego" rozumowania ekonomistów był John Stuart Mill (1806-1873), w badaniu człowieka stosujący dedukcyjną metodę wywodu, w której to najważniejsze są same założenia teorii, natomiast dane empiryczne niekoniecznie musiały ją potwierdzać, bo ważniejsza była logiczność wywodu i argumentacji ${ }^{2}$. Warto zwrócić uwagę na to, że ekonomia do końca XIX wieku była połączona z filozofią moralną, a ekonomia dopiero za sprawą rewolucji marginalistycznej i Alfreda Marshalla zaczęła swój mariaż z matematyką̧3.

\section{Pozytywizm}

W wieku XIX nauka zaczęła cieszyć się coraz większą estymą, a precyzując, poważanie zyskały wśród intelektualistów nauki ścisłe. Wzrost znaczenia nauki był spowodowany coraz większą liczbą odkryć związanych głównie z naukami, takimi jak biologia, fizyka czy chemia. Powiązana z tymi odkryciami rewolucja przemysłowa spowodowała, że zauważono, w jak znacznym stopniu nauka może oddziaływać na życie ludzi. Odbiciem tej popularności nauki było powstanie we Francji, po rewolucji z 1789 roku, szkół ecoles centrales, w których naukę ograniczono prawie wyłącznie do nauk ścisłych. Szkoły te kształciły inżynierów wierzących w uporządkowany, racjonalny świat, który można wyjaśnić za pomocą rozumu. Tę wiarę w rozum nazwano pozytywizmem, a jego głównym ambasadorem był August Comte (1798-1857). Powstał kult nauki, którą uważano za najwyższy sposób poznania. Panowało przekonanie, że nauka, odkrywając stopniowo własności świata, rozwija się kumulatywnie. Zasób posiadanej przez ludzi wiedzy ciągle się powiększa, dlatego możemy mówić o postępie eksploatacyjnym nauki, co z kolei zapewnia rozwój technologiczny. Wiarą kultury oświeceniowej było przekonanie, że ludzkość przez stopniowy

${ }^{2}$ Należy zaznaczyć, że o ile w naukach społecznych Johna Stuarta Milla można uznać za zwolennika metody dedukcyjnej, o tyle ogólnie jest on znany jako entuzjasta metody indukcyjnej (przedstawił rozwinięcie indukcji eliminacyjnej przez wprowadzenie kanonów). Co jednak istotne, angielski ekonomista dorabiał dodatkowe założenia, co miało na celu utrzymanie teorii Thomasa Malthusa i Davida Ricardo, które zostały obalone przez dane empiryczne [Blaug 1995, s. 110-118].

3 Dopiero w roku 1896 Henry Sidgwick i ekonomista Alfred Marshall, którzy razem pracowali na tym samym wydziale w Cambridge, postanowili założyć oddzielny wydział ekonomii [Rawls 2010, s. 235]. 
rozwój dąży do ideału4. Taka fetyszyzacja nauki, za pomocą której wszystko można wyjaśnić, została później mocno skrytykowana przez Friedricha Hayeka, określającego to zjawisko jako ,pycha rozumu"s.

Takie przywiązanie do nauk ścisłych miało wpływ na nauki społeczne, szczególnie na socjologię, którą August Comte przez długi czas nazywał fizyką społeczną. Pozytywiści, rozmiłowani w naukach przyrodniczych i ich praktyczności, uznali, że metody nauk ścisłych można przełożyć na nauki społeczne, wykorzystując je do opisywania człowieka i społeczeństwa. Ta wiara w znaczenie i elegancję nauk ścisłych będzie miała później szczególny wpływ na jedną z nauk społecznych - na ekonomię.

\section{Rewolucja marginalistyczna}

Rewolucja marginalistyczna jest początkiem intensywnego wpływu matematyki na ekonomię. Nie tylko ze względu na wprowadzenie modeli i wzorów, ale głównie dlatego, że marginaliści sprowadzili człowieka do prostego kalkulatora, który liczy swoją przyjemność i według tego podejmuje decyzje ${ }^{6}$. To właśnie w wyniku rewolucji marginalistycznej wykrystalizował się homo oeconomicus, którego wykorzystała później ekonomia neoklasyczna w modelach opisujących rzeczywistość.

W latach 70. XIX wieku trzech ekonomistów w kilka lat doszło do podobnych wniosków. Ważni w aspekcie wpływu matematyki na ekonomie będą Léon Walras i William Stanley Jevons. Nie można wliczać do tego grona trzeciego ekonomisty Carla Mengera, gdyż był bardzo nieprzychylny matematyce, sądząc, że za jej pomocą nie można obliczyć czynników jakościowych, takich jak cechy psychologiczne. Do dziś zwraca na to uwagę szkoła austriacka, uważając, że ekonomia neoklasyczna w sposób nieuprawniony uprościła naturę człowieka za pomocą matematyki.

Określenie „rewolucja” nie było przypadkowe, ponieważ od końca XIX wieku głównym zainteresowaniem ekonomii przestała być produkcja bogactwa, a stało się nią zdobywanie użyteczności za sprawą konsumpcji. Bardzo wiele William Stanley Jevons zawdzięcza Jeremiemu Benthamowi (1748-1832) i utylitaryzmowi. Za ich sprawą Jevons przyjął, że człowiek dąży do maksymalizacji użyteczności z konsumpcji. Użyteczność natomiast, tak jak w utylitaryzmie, ma dwa wymiary: długość trwania i intensywność przyjemności (bądź bólu). Większa przyjemność jest prefe-

${ }^{4}$ Próbą zebrania całej wiedzy ludzkości była Wielka encyklopedia francuska wydawana w okresie 1751-1780 w 35 tomach przez zespół pod kierownictwem D. Diderota i J. d’Alemberta. W skład zespołu wchodzili m.in.: Voltaire, Charles Louis de Montesquieu, Jean Jacques Rousseau, Étienne Bonnot de Condillac.

${ }^{5}$ Friedrich Hayek zwracał uwagę, że nowożytny racjonalizm, będący podstawą sukcesów nauki $\mathrm{i}$ techniki, występuje również w wynaturzonej postaci scjentyzmu prowadzącego prostą drogą do zniewolenia człowieka [Hayek 2013].

6 „Hedonistyczna koncepcja postrzega człowieka jako kalkulator przyjemności i bólów, który oscyluje jak jednorodna kula poszukująca szczęścia, pod wpływem bodźców, które miotają nią, lecz pozostawiają nienaruszoną" [Veblen 1989]. 
rowana w stosunku do mniejszej, ale wraz ze wzrostem spożycia danego dobra spada jego użyteczność, co stanowi istotę prawa malejącej użyteczności krańcowej. Co ważne, stojąc przed wyborem dwóch dóbr, człowiek będzie zwiększał użyteczność z ich konsumpcji, dopóki użyteczność krańcowa jednostki pieniężnej wydawanej na zakup któregokolwiek z nich stanie się równa użyteczności krańcowej jednostki pieniężnej wydawanej na drugie dobro, co znane jest w ekonomii pod postacią drugiego prawa Gossena. Dzięki takiemu podejściu ekonomista - w uproszczeniu - jest w stanie np. powiedzieć, że człowiek woli dwa jabłka niż jednego banana. $\mathrm{Z}$ powodu takiego matematycznego rozumowania (maksymalizacja i korzystanie $\mathrm{z}$ rachunku różniczkowego w liczeniu zmian stosunku dóbr) przyjęto założenie, że człowiek dokonuje skomplikowanych obliczeń, by podjąć decyzje [Morgan 1996].

Dwoma głównymi osiągnięciami rewolucji marginalistycznej było odejście od teorii obiektywnej na rzecz teorii subiektywnej, a także wprowadzenie języka matematycznego do ekonomii. Nie może dziwić takie matematyczne podejście, jeżeli spojrzymy na życiorys Williama Stanleya Javonsa, który w młodości studiował chemię i do końca życia miał bardzo dużo poważania dla nauk ścisłych - dlatego w swoich przemyśleniach próbował wykorzystać metodologię fizyczną. Można zauważyć duży wpływ prawa zachowania energii podczas konstrukcji krzywych użyteczności i rachunku marginalnego [Mirowski 1988, s. 19-22]. Taki uproszczony model człowieka, dążący wyłącznie do maksymalizacji użyteczności, był krytykowany za czasów Jeremy'ego Benthama i został określony jako „system dobry dla świń"7. Tym razem krytyka była dużo większa i pochodziła głównie ze szkoły instytucjonalnej, która z czasem coraz bardziej oddalała się od głównego nurtu ekonomii.

Bardzo duży wpływ na ukształtowanie dzisiejszej ekonomii miał francuski ekonomista Léon Walras. Jego główne osiągnięcie to próba wykazania, że na rynku powstaje naturalna równowaga, co było możliwe dzięki krzywym użyteczności i możliwości ich liczenia przez ceny, jakie musimy płacić za pożądane produkty. W pewnym stopniu taki rodzaj liczenia użyteczności można uznać za odpowiedź na słynny hedonometr stworzony przez Francisa Edgewortha (1845-1926) ${ }^{8}$. Z powodu rewolucji marginalistycznej takim hedonometrem stały się ceny, dzięki którym można było dowiedzieć się „wszystkiego” o wyborach ludzi i na tej podstawie tworzyć modele dotyczące ludzkich zachowań.

Za głównego popularyzatora matematycznej ekonomii można z kolei uznać Alfreda Marshalla, którego zasady ekonomiki stały się głównym podręcznikiem z zakresu ekonomii i dzięki któremu po raz pierwszy w takim stopniu wykorzystano wzory i modele. Szczególną popularnością do dziś cieszą się krzywe popytu i podaży, po raz pierwszy użyte przez Alfreda Marshalla. Mimo korzystania z matematyki Alfred Marshall zwracał uwagę, że matematyka pełni w ekonomii funkcje języka,

7 Takich porównań dokonywali już wcześniej przeciwnicy Epikura.

${ }^{8}$ Hedonometr to wyimaginowany instrument, stanowiący odpowiednik termometrów w stacjach meteorologicznych, który mierzyłby aktualny poziom przyjemności lub przykrości odczuwanej przez osobę. 
a nie narzędzia badawczego [Sedlacek 2012, s. 298]. Ma służyć ekonomii, a nie warunkować jej wnioski. Najlepiej te poglądy wyraża Marshall w liście napisanym w 1906 roku do Arthura Lyona Bowleya, kiedy podsumowuje swoje kilkudziesięcioletnie doświadczenie ekonomiczne: „W miarę upływu lat mojej pracy rośnie we mnie przekonanie, że jest bardzo mało prawdopodobne, by dobre twierdzenie matematyczne odnoszące się do hipotez gospodarczych było jednocześnie dobrą ekonomią, dlatego coraz częściej stosowałem się do następujących reguł: (1) Wykorzystuj matematykę jako język skrótu myślowego, a nie jako maszynerię badań. (2) Badaj ten matematyczny model, aż będziesz zadowolony. (3) Przetłumacz to na angielski (wyraź to w języku naturalnym). (4) Znajdź dobre przykłady z realnego życia ilustrujące twoje dokonania teoretyczne. (5) Spal matematykę. (6) Jeżeli nie udało ci się zrealizować (4), spal także (3). To ostatnie robiłem często" [Weintraub 2002]. Pomimo przestróg Alfreda Marshalla matematyka w następnych latach zaczęła zajmować coraz więcej miejsca $\mathrm{w}$ ekonomii $\mathrm{i}$ jest to $\mathrm{w}$ znacznej mierze zasługa tego badacza.

\section{Rewolucja formalistyczna}

Nie rzeczywistość. Proszę. My jesteśmy ekonomistami.

[Blaug 2001] $]^{9}$

Osiągnięcia rewolucji marginalistycznej nie od razu zostały zaakceptowane przez środowisko ekonomiczne. Szczególnie dużą niechęć wyrażano w stosunku do myślenia związanego z użytecznością i wykorzystaniem matematyki. Również wielki kryzys z 1929 roku podważył teorię ogólnej równowagi i spowodował, że ekonomiści odnosili się do niej nieufnie. Jednak z drugiej strony coraz większa liczba naukowców z różnych dziedzin chciała mieć swój wkład w tworzenie „lepszego” społeczeństwa. Uważali, że aparat metodologiczny nauk ścisłych można wykorzystać podczas uporządkowywania społeczeństwa, co było atrakcyjne, mając na względzie niski poziom nauk społecznych ${ }^{10}$.

W latach 50. upowszechnił się paradygmat związany z ekonomią neoklasyczną, który stał się głównym nurtem ekonomii i ma taki charakter aż do dzisiaj. Zgodnie z teorią struktur naukowych Thomasa Kuhna [Kuhn 2009] możemy stwierdzić, że ustalenie się poglądu neoklasycznego nie wynikało z ewolucyjnego rozwoju nauki ekonomicznej, lecz z tego, że w po II wojnie światowej ten sposób myślenia był najpopularniejszy i dużo skuteczniejszy niż reszta konkurencyjnych paradygmatów ekonomicznych. Można zaryzykować twierdzenie, że to głównie dzięki matematycznemu aparatowi teoria neoklasyczna stałą się dominującą teorią ekonomiczną.

\footnotetext{
9 Jest to parafraza tytułu musicalu.

${ }^{10}$ Friedrich Hayek zwracał uwagę na niebezpieczną chęć uporządkowania społeczeństwa za pomocą reguł i norm, co czynił w swojej książce Droga do zniewolenia [Hayek 2003].
} 
Lata 50. można określić jako rewolucję formalistyczną w ekonomii. W krótkim czasie uproszczone i zmatematyzowane spojrzenie na rzeczywistość i człowieka stało się dominującym poglądem w ekonomii, a formalizm stał się naukowym esperanto. Po II wojnie światowej nastąpił znaczny wzrost publikacji ekonomicznych wykorzystujących matematykę, zawdzięczających swoją popularność prostocie, efektywności i obiektywności [Debreu 1991]. Matematyzacja ekonomii spowodowała upowszechnienie się opinii, że ekonomia jest niemal tak „twarda”, jak nauki ścisłe i daleka od innych, „bardziej miękkich” nauk społecznych. Należy również zwrócić uwagę na ahistoryczność metod ortodoksyjnej ekonomii, w której prawa ekonomiczne są jak prawa przyrodnicze: funkcjonują niezależnie od historii, są obiektywne, odrębne od społecznej rzeczywistości i można je poznać przez doświadczenie. Co równie istotne, w ortodoksyjnej ekonomii realizowany jest przyrodniczy ideał poznania naukowego, rozumiany jako neutralny aksjologicznie, możliwie precyzyjny, niezawierający elementów wartościujących opis faktualnej rzeczywistości gospodarczej [Zboroń 2013]. Dzięki przyjęciu tej metodologii upowszechnił się pogląd, że ekonomia osiągnęła najszybszy rozwój ze wszystkich nauk społecznych ${ }^{11}$ (rozwój ujmowany z punktu widzenia kryterium siły predykcji czy też realizmu instrumentalnego).

Ważnym aspektem, który umocnił postulat Wertfreiheit ${ }^{12}$ (niem. wolność od wartościowania) ortodoksyjnej ekonomii, było wykorzystanie koncepcji darwinizmu społecznego ${ }^{13}$, spopularyzowanego przez Herberta Spencera. Jest ona wykorzystywana, zwłaszcza kiedy mówimy o tym, że na rynku zostają najsilniejsi, a odpadają najsłabsi. Takie ujęcie powoduje, że ekonomia, wierząc w rynek, „usprawiedliwia” porażki podmiotów gospodarczych. Dzięki temu, nie oceniając tego zjawiska, ekonomia może wydawać sądy pozytywne, a nie normatywne, czym się szczyci, a co odróżnia ją od innych nauk społecznych ${ }^{14}$. Obiektywność ekonomii wśród nauk społecznych wynika również z tego, że ekonomia posługuje się trzema fundamentalnymi i unikatowymi dla analizy ekonomicznej pojęciami: maksymalizacji korzyści, równowagi i efektywności [Lazear 1999], skutecznie i owocnie stosując je w badaniach zjawisk pozaekonomicznych, wypierając inne dziedziny wiedzy z ich własnego obszaru badawczego, co nazwano imperializmem ekonomicznym i utożsamiane jest głównie z Garym Beckerem.

${ }^{11}$ Jednak z czasem ta metodologia została poddana surowej krytyce razem z całą koncepcją pozytywizmu. Kompleksową krytykę i analizę wad myślenia ekonomicznego przeprowadził Bruce. J. Caldwell w książce Beyond Positivism: Economic Methodology in the Twentieth Century [Caldwell 1994].

12 Termin wprowadzony przez Maksa Webera.

${ }^{13}$ Nie należy włączać tutaj założeń ekonomii ewolucyjnej, która stoi w opozycji do ekonomii neoklasycznej [Kwaśnicki 2001].

14 Trzeba uważać, żeby nie wpaść w pułapkę błędu naturalistycznego opisanego przez George’a Moore'a [Moore 1903]. To, że natura (w tym wypadku rynek) w żadnym stopniu nie implikuje tego, że tak powinno być. Oczywiście błąd naturalistyczny odnosi się do słynnej gilotyny Hume’a, dotyczącej niemożności wnioskowania o tym, co powinno być, na podstawie tego, co jest (is-ought problem) [Hume 1965, s. 469 ]. 
Za Ludwigiem Wittgensteinem można powiedzieć: ,granice mojego języka wskazują granice mego świata" [Wittgenstein 1970, s. 5, 6]. Skoro językiem ekonomistów stała się matematyka, to trzeba się liczyć z ograniczeniem świata opisywanego przez ekonomistów. Tak też się stało i rzeczywistość ekonomiczna była coraz węziej analizowana i coraz bardziej idealizowana, przez co znacznie oddaliła się od rzeczywistości.

Osobą, która sprawiła, że dzisiejsza ekonomia jest utożsamiana z ekonomią neoklasyczną, jest Paul Samuelson, którego podręczniki do ekonomii kształtowały poglądy milionów studentów po II wojnie światowej. Czytając podręcznik Samulesona, ma się wrażenie obcowania z matematyką, a nie nauką społeczną. Na większości stron znajdują się wzory i wykresy. Najważniejszy jest jednak człowiek, który u Paula Samuelsona staje się racjonalnym agentem, zawsze maksymalizującym swoją użyteczność. „Pogląd, że konsument maksymalizuje swoją użyteczność nie jest tylko prawem ekonomii, ale jest prawem logiki samym w sobie" [Ainslie 2001, s. 8]. Amerykański ekonomista uważał, że ekonomia jest naturalnie mierzalna i dlatego prowadzi do matematycznej analizy. Co więcej, nie widział on problemu z przekładaniem języka ojczystego na język matematyczny, ponieważ „matematyka to język" [Bleed, Kane 1991].

Z czasem rosła swoista arogancja ekonomistów, którzy uważali, że dzięki korzystaniu z metodologii nauk przyrodniczych ${ }^{15}$ i matematycznych modeli są w stanie usprawniać działanie społeczeństw. Ekonomia coraz bardziej przybliżała się do polityki, ponieważ jako jedyna z nauk społecznych dawała obietnicę konkretności i skuteczności swoich metod. Neoklasycy, uważając, że prawa ekonomii są ahistoryczne i niekwestionowalne, uznali, że w każdym kraju, bez względu na sytuację społeczną, można zastosować takie same środki ekonomiczne. Szczególnie uwierzyli w to tzw. chłopcy z Chicago ${ }^{16}$, których eksperymenty z wykorzystaniem środków zalecanych przez neoklasyczną teorię zakończyły się katastrofą dla wielu krajów z Ameryki Południowej. Chicagowscy ekonomiści zapomnieli o udziale społeczeństwa i czynników instytucjonalnych, o czym wcześniej ostrzegał Karl Polanyi w Wielkiej transformacji, w której przekonywał, że człowieka nie można określić tylko za pomocą modelu homo economicus [Polanyi 2011].

Z kolei Mark Blaug [Blaug 1998] uważał, że koncepcja równowagi rynkowej Arrowa i Debreu to początek raka trawiącego od tego czasu mikroekonomię. Kenneth Arrow i Gérard Debreu dali matematyczny dowód na równowagę rynkową, o której pisał Léon Walras, ale której nie potrafił udowodnić. Oni dali ten dowód, ale naruszając rzeczywistość ekonomiczną i zastępując ją logiką matematyczną. To od

${ }^{15}$ W tym zwłaszcza z fizyki.

${ }^{16}$ Grupa ok. 25 chilijskich ekonomistów pracujących w administracji rządu Augusto Pinocheta (lata 70. XX wieku). Większość z nich studiowała w Szkole Ekonomii na Universidad Católica w Chile oraz na University of Chicago w USA, gdzie uczyli się od Miltona Friedmana i innych przedstawicieli chicagowskiej szkoły ekonomii. Napisali manifest wzywający do natychmiastowej reprywatyzacji państwowych przedsiębiorstw w Chile. Określenia tego użyła amerykańska prasa. 
tego momentu bardzo często w ekonomii zaczęło chodzić o to, aby modele „się zgadzały”, mimo niezgodności z rzeczywistością. Dla Walrasa równowaga rynkowa była pewnego rodzaju idealizacją, a od argumentacji Arrowa i Debreu przyjęło się ją za dogmat. Ronald Coase określił taki sposób myślenia jako ekonomię „szkolnej tablicy" [Coase 2013, s. 18], czyli tworzenia modelu, w którym korzystamy z pojęć, takich jak: ceny, wielkości, czynniki produkcji, które nigdy nie są wystarczające do opisu rzeczywistości ${ }^{17}$. Co równie ważne, model Arrowa i Debreu doprowadził do powstania wiary w doskonałą konkurencję i odejścia od myślenia Adama Smitha, dla którego rozwój produktów i niższe ceny wynikają z natury ludzkiej i naturalnej konkurencji miedzy sobą. W koncepcji Arrowa i Debreu to nie firmy kształtują ceny, ale stają się ich odbiorcami, ponieważ taka jest struktura rynku. Ta subtelna zmiana miała wpływ na całe pojmowanie rzeczywistości przez ekonomię [Blaug 1998].

Równie wielki wpływ na ukształtowanie metodologii ekonomii miał Milton Friedman. Krytykował on podział ekonomii na ekonomię pozytywną, normatywną i sztukę ekonomii ${ }^{18}$. Przedmiotem ekonomii w jego opinii powinna być ekonomia pozytywna, zajmująca się identyfikowaniem określonych prawidłowości na rynku, które można ująć w teorię i prawa, dzięki czemu można dokonywać empirycznego testowania. Modele i teorie według Miltona Friedmana mają służyć jako instrumenty do przewidywania, bez względu na realność założeń (liczy się siła predykcyjna). W ten sposób kończy się epoka traktowania ekonomii jako nauki czysto dedukcyjnej. Bardzo ważne stają się dane empiryczne. Liczba hipotez mogących wyjaśniać określone zjawiska może być nieskończona, dlatego trzeba wybrać hipotezę czyniącą to najlepiej. Kryterium tego wyboru jest prostota i owocność (fruitfulness). Milton Friedman przejmuje więc założenie ortodoksyjnej ekonomii, że u podstaw badanych zjawisk leżą w istocie proste prawa (na wzór praw fizyki), które pozostaje odkryć, proponując i testując coraz nowsze teorie [Gorazda 2014, s. 286].

Duży wpływ na matematyzację ekonomii miała również teoria gier, po raz pierwszy opracowana przez Johna von Neumana i Oskara Morgensterna w opublikowanej w 1944 roku pracy pt. Teoria gier i zachowanie ekonomiczne. Od razu zdobyła ona uznanie w świecie nauki, największe wśród ekonomistów, spośród których kilku zdobyło Nagrodę Nobla, właśnie za wykorzystanie teorii gier ${ }^{19}$. Wydaje się ona idealnie „skrojona” pod ekonomistów. Mamy w niej do czynienia z uproszczoną rzeczywistością, w której racjonalni agenci wchodzą ze sobą w interakcje

${ }^{17}$ Coase był bardzo zadecydowanym przeciwnikiem matematyzacji ekonomii i wielokrotnie dość ostro się do niej odnosił: „W mojej młodości mówiło się, że to, co jest zbyt głupie do powiedzenia, można zaśpiewać. We współczesnej ekonomii można to załatwić za pomocą matematyki” [Coase 2013, s. 169].

${ }^{18}$ Różnice między tymi trzema rodzajami ekonomii wprowadził John Neville Keynes (ojciec Johna Mayndarda) [Keynes 1890].

${ }_{19}$ Ekonomiści, tacy jak: Herbert Simon, John Nash, Reinhard Selten, John Harsanyi, William Vikcery, James Mirrlees, Thomas Schelling, RobertAuman, Leonid Hurwicz, Eric Maskin, Roger Meyrson. 
i próbują maksymalizować swoją użyteczność, wyrażoną w pieniądzach albo innych jednowymiarowych zmiennych, oznaczających wypłatę. Mimo abstrakcyjności założeń, ekonomiści bardzo szybko zaczęli wyciągać wnioski z teorii gier i nie zważali na to, że dotyczy ona szczególnych przypadków i nie jest w stanie opisać skomplikowanej rzeczywistości, w której ludzie codziennie podejmują decyzje.

Powracając do Ludwiga Wittgensteina, warto zwrócić uwagę na to, jak istotny w kontekście matematyzacji jest sam język, którym posługuje się ekonomia. Deridre McCloskey [McCloskey 1983] zwróciła uwagę na wykorzystywanie w ekonomii kilku strategii retorycznych, których celem było wzmocnienie pozycji ekonomii jako wiodącej dyscypliny społecznej oraz nadanie dyskursowi ortodoksyjnemu dominującej pozycji. Często ekonomia korzysta z określeń stosowanych w języku fizyki jako metafor do opisu zjawisk gospodarczych. Przyzwyczajenie językowe sprawia, że po jakimś czasie metafory przybierają postać skonwencjonalizowaną i są traktowane metonimicznie. Takie wyrażenia, jak „równowaga”, „cyrkulacja”, „elastyczność”, „cykliczność” i wiele innych, sugerują, że zjawiska opisywane w ekonomii, podobnie jak zjawiska fizyczne, podlegają obiektywnym prawom mającym status podobny do praw fizyki. Inną strategią retoryczną jest językowa obiektywizacja praktyki gospodarczej. Polega ona na eliminowaniu z opisów gospodarki człowieka jako podmiotu wyborów ekonomicznych. Przykładami są określenia: ,wahania rynku”, „oczekiwania rynku”, „wycena rynkowa”, ,rynek reprezentowany przez krzywe podaży i popytu". Takie określenia sprawiają, że rynek wydaje się podmiotem, którego zachowania nie można kontrolować. Warto również zwrócić uwagę, że w ekonomii często określamy człowieka terminem ,agent”, które to sformułowanie od razu przywołuje obraz racjonalnej jednostki, podążającej za własnym interesem, będącej zupełnym przeciwieństwem freudowskiego człowieka miotanego nieuświadomionymi impulsami.

\section{Szaleństwo prognozowania}

Rozwój ekonomii matematycznej, a w szczególności ekonometrii, sprawił że uwierzono, iż wszystko można wyliczyć, jeżeli ma się do czynienia z dostatecznie dobrym modelem. Matematyka i dostęp do danych sprawiły, że ekonomiści uwierzyli, że są w stanie za pomocą nauki prognozować przyszłość. Naturalne wydawało się wykorzystanie takich zdolności przewidywania w przypadku giełdy. W 1900 roku francuski matematyk Lois Bachelier napisał dysertację doktorską o ruchu cen akcji na paryskiej giełdzie. Odkrył, że za pomocą rozkładu normalnego - krzywych Gaussa, można przedstawić wpływ każdego uczestnika na giełdę [Fox 2009, s. 6]. Z tego pomysłu skorzystał Irving Fisher, tworząc swoją teorię błądzenia losowego, która jednak nie uchroniła go przed stratą wszystkich pieniędzy podczas czarnego piątku 1929 roku. W celu przewidywania ceny na giełdzie nie korzystano tylko z teorii matematycznych, ale też i z modelu homo oeconomicus, czego najlepszym przykładem jest hipoteza racjonalnego rynku Eugene'a Famy, w którym cena aukcji na gieł- 
dzie odpowiada „prawdziwej” ich wartości właśnie dlatego, że człowiek jest racjonalny. Jednak z przykładem największej wiary w zdolności prognostyczne mieliśmy do czynienia w roku 1993, kiedy dwóch noblistów z ekonomii: Robert Merton i Myron Schole, stworzyło fundusz, który korzystając z wiedzy statystycznej, miał być źródłem niekończących się zysków. Jednak kilka lat później fundusz zbankrutował, co dziwić nie może, jeżeli zwrócimy uwagę na to, jak nieprzewidywalny jest świat, w którym żyjemy.

Z próbami przewidywania przyszłości mieliśmy do czynienia od początków istnienia ludzkości, jednak to właśnie ekonomia sprawiła, że nadano tym prognozom nimb naukowości, tak jak kiedyś wróżbici tworzyli wokół siebie atmosferę tajemniczości. Powinniśmy wyciągnąc naukę z błędów Thomasa Malthusa i jego teorii, a także z porażki przewidywań Klubu Rzymskiego ${ }^{20}$. Co ważne, za czasów Thomasa Malthusa ekonomia była uważana za dismal science, za naukę, która może przewidywać przyszłość, ale nie jest w stanie jej zmienić. Natomiast wiara w modele ekonometryczne sprawiła, że uwierzono, że teraz ekonomia jest w stanie nie tylko przewidywać przyszłość, a co najważniejsze, że może ją kształtować.

Problemem ekonomii jest to, że dzięki matematyce zdobyła naukowe przyzwolenie, by prognozować przyszłość. Dzięki temu stała się najważniejszą z nauk społecznych, z której usług zaczęli korzystać politycy. Z tego powodu dzisiaj mamy do czynienia z korowodem ekonomistów, codziennie odpowiadających na pytanie, jaka będzie przyszłość, mimo że nie są w stanie tego określić. Ekonomiści stali się ekspertami od przyszłości, który to pogląd skrytykował Nassim Taleb. Czarne łabędzie, opisane w jego książce [Taleb 2014], to zdarzenia, których nie można przewidzieć ani wywnioskować z wcześniejszej historii. Ekonomiści często o tym zapominają, chowając się za zasłoną poziomu ufności, który ma urealnić ich przewidywania. Niewątpliwie jest to zbyt mało - trzeba pamiętać o tym, jak bardzo skomplikowana jest rzeczywistość, w której funkcjonujemy i którą można sprowadzić do prostego matematycznego modelu.

Rosnąca arogancja ekonomistów szła w parze ze zwiększeniem wiary w ekonometrię, co było spowodowane rozwojem technologii komputerowej. Dzięki temu ekonomiści zdobili dostęp do ogromnej ilości danych, które można łatwo liczyć i mierzyć. Ta wiedza spowodowała, że w bloku sowieckim chciano wyliczać optymalne ceny. Wydawać by się mogło, patrząc na porażki prognozowania ${ }^{21}$, że ekonomiści spokornieją, ale tak nie było. Tę pewność siebie można zauważyć w sektorze bankowym, w którym „dokładnie” wyliczano ryzyko instrumentów finansowych. Użycie skomplikowanych procedur ${ }^{22}$ sprawiło, że nikt nie wiedział, z czym napraw-

${ }^{20}$ Nie chodzi tutaj o polemikę dotyczącą tego, na ile przewidywania Klubu Rzymskiego się sprawdziły lub nie sprawdziły, lecz o zauważenie faktu, że niemożliwe jest uchwycenie wszystkich możliwości w modelu statystycznym. Jest to skutkiem faktu, że pewnych zmian nie możemy przewidzieć.

${ }^{21}$ Dramatyczny upadek gospodarek centralnie planowanych.

${ }^{22}$ Głównie chodzi tu o CDO, czyli instrumenty sekurytyzacji oparte na długu. 
dę ma do czynienia. Kryzys z 2008 roku nie otrzeźwił niektórych ekonomistów, którzy winą za załamanie gospodarcze obarczyli ludzi z ich nieracjonalnością i ze „Zwierzęcymi instynktami”, twierdząc, że nieracjonalne zachowania nie pasują do ich modeli i teorii, i dlatego nie udało im się przewidzieć kryzysu - jak gdyby to ludzie mieli się dopasowywać do modeli, a nie na odwrót ${ }^{23}$.

Należy jeszcze wspomnieć o fetyszyzacji wskaźnika PKB, który w ostatnich latach poddano ostrej krytyce ${ }^{24}$. Próby stworzenia nowych mierników ludzkiego dobrobytu pokazują, jak trudno na podstawie parametrów ocenić ludzkie życie, szczególnie jeżeli chodzi o ocenę poziomu zadowolenia z życia.

Problemem z wykorzystywaniem matematyki w ekonomii jest również to, że często ekonomiści sami nie rozumieją jej metod i korzystają z matematyki, aby sprawić, by artykuły naukowe wyglądały bardziej „,naukowo”. Można przyrównać takie zachowania do stosowania greki czy łaciny w 1900 roku, co uważano za przykład erudycji i dobrego wyksztalcenia - takie umiejętności jednak mają na celu łechtanie ego mówiącego, niż mają praktyczny sens. Popularność stosowania matematyki wynika również z tego, że łatwiej opublikować takie prace w najlepszych czasopismach naukowych, bo przez zasłonę wzorów i modeli ciężej zauważyć błędy w myśleniu. Wiara w charakter niezaprzeczalności wielu ekonomicznych teorii spowodowała, że często ekonomiści korzystają z danych teorii, aby wyjaśnić wszystkie zjawiska. Możliwość argumentowania „zgodnie z teorią” powoduje problemy w dyskusjach między przeciwstawnymi poglądami, a także skutkuje umysłowym lenistwem, gdy teorię traktujemy jak wiarę i nie jesteśmy w stanie dostrzec rys w jej obrazie.

\section{W poszukiwaniu nowego paradygmatu}

Arcydzieło literatury światowej $W$ poszukiwaniu straconego czasu Marcela Prousta to cykl książek, pokazujących czytelnikowi, jak bardzo liczą się drobne elementy, nadające życiu określone zabarwienie. Na to samo w neoklasycznej ekonomii od lat zwracają uwagę inne nauki. Szczególnie krytykowany jest uproszczony model homo economicus i jego założenia. Krytykę tę głównie wyrażają przedstawiciele ekonomii behawioralnej, która pokazuje, jak mocno odbiega od rzeczywistości model homo economicus, na którym zbudowana jest dzisiejsza neoklasyczna ekonomia ${ }^{25}$.

Nie chodzi o to, że matematyka jest ekonomii niepotrzebna i nie powinniśmy stosować modeli i założeń upraszczających rzeczywistość. To niezwykle pożyteczne narzędzia, z których ekonomiści mogą się wiele dowiedzieć. Matematyka ma być jednak tylko narzędziem wykorzystywanym przez ekonomię, a nie celem samym w sobie. Ma pomóc opisywać rzeczywistość, a nie ją zastępować. Powinna stanowić

${ }^{23}$ Oczywiście, modele muszą upraszczać rzeczywistość, ale ich założenia muszą być prawidłowe.

${ }^{24}$ Większość z zastrzeżeń zawarto w książce Błąd pomiaru. Dlaczego PKB nie wystarcza [Fitoussi, Sen, Stiglitz 2013].

${ }^{25}$ Zob. [Frank1989; Kahneman, Tversky 1979; Kahneman 2003; Scitovsky 1992; Rabin 1998; Sen 1977; Thaler 1980; 2000; 2015]. 
szkielet budowli, który dopełnimy, korzystając z dorobku innych nauk. Trzeba sprawdzić, co do powiedzenia ma dziś ekonomia, bez całego aparatu matematycznego, by się nie okazało, że: „Być może współczesna teoria ekonomii nie jest niczym więcej jak XVI medycyna ubrana w XX wieczne matematyczne ubrania” [Bleed, Kane 1991], by się nie okazało, że król jest nagi.

\section{Literatura}

Ainslie G., 2001, Breakdown of Will, Cambridge University Press.

Blaug M., 1995, Metodologia ekonomii, Wydawnictwo Naukowe PWN, Warszawa.

Blaug M., 1998, Disturbing currents in modern economics, Challenge, vol. 41, no. 3, s. 11-34.

Blaug M., 2001, No history of ideas, please, we're economists, Journal of Economic Perspectives, vol. 15 , no. 1, s. 145-164.

Bleed C., Kane O., 1991, What is the critique of the mathematization of economics?, Kyklos, vol. 44, issue 4, s. 581-612.

Caldwell B.J., 1994, Beyond Positivism: Economic Methodology in the Twentieth Century, Routledge, rev. ed. edition.

Coase R.H., 2013, Firma, rynek i prawo, Wolters Kluwer, Warszawa.

Debreu G., 1991, The mathematization of economic theory, The American Economic Review, vol. 81, no. 1.

De Soto H., Myśl ekonomiczna w starożytnej Grecji, http://mises.pl/blog/2010/12/06/ huerta-de-sotomysl-ekonomiczna-w-starozytnej-grecji/ (1.04.2014).

Fitoussi J.P., Sen A., Stiglitz J., 2013, Błą pomiaru. Dlaczego PKB nie wystarcza, Polskie Towarzystwo Ekonomiczne, Warszawa.

Fox J., 2009, The Myth of Rational Markets, Harper Business, New York.

Frank R.H., 1989, Passions Within Reasons, W.W. Norton \& Company.

Gorazda M., 2014, Filozofia ekonomii, Copernicus Center Press.

Hayek F.A., 2003, Droga do zniewolenia, Wydawnictwo Arcana, Kraków.

Hayek F.A., 2013, Nadużcie rozumu, Prohibita, Warszawa.

Hume D., 1965(1740) A Treatise of Human Nature, Oxford, Clarendon Press. .

Kahneman D., 2003, A psychological perspective on economics, The American Economic Review, vol. 93 , no. 2 .

Kahneman D., Tversky A., 1979, Prospect theory: An analysis of decision under risk, Econometrica, no. $47(2)$.

Keynes J.N., 1999, The Scope and Method of Political Economy, Batoche Books.

Kuhn T.S., 2009, Struktura rewolucji naukowych, Aletheia, Warszawa.

Kwaśnicki W., 2001, Ekonomia ewolucyjna - w poszukiwaniu alternatywnego wyjaśnienia rzeczywistości społeczno-gospodarczej, http://prawo.uni.wroc.pl/ kwasnicki/ todownload/KongresEk2001.pdf.

Lazear P.E., 1999, Economic imperialism, NBER Working Paper, no. 7300.

McCloskey D.N., 1983, The rhetoric of economics, Journal, of Economic Literature, vol. 21, no. 2, s. 481-517.

Mirowski P., 1988, Against Mechanism: Protecting Economics from Science, Rowman \& Littlefield.

Moore G.E., 2004, Principia Ethica, Dover Publications.

Morgan M.S., 1996, The character of "rational economic man", London School of Economics \& Political Science, Working Papers in Economic History, 34 (96).

Polanyi K., 2011, Wielka transformacja, PWN, Warszawa. 
Rabin M., 1998, Psychology and economics, Journal of Economic Literature, vol. 36, no. 1.

Rawls J., 2010, Wykłady z historii filozofii polityki, Wydawnictwa Akademickie i Profesjonalne, Warszawa.

Scitovsky T., 1992, The Joyless Economy, Oxford University Press, Oxford.

Sedlacek T., 2012, Ekonomia dobra i zła, Studio Emka, Warszawa.

Sen A., 1977, Rational fools: A critique of the behavioural foundations of economic theory, Philosophy and Public Affairs, no. 6 (4).

Taleb N.N., 2014, Czarny łabędź. O skutkach nieprzewidywalnych zdarzeń, Kurhaus Publishing, Warszawa.

Thaler R.H., 1980, Toward a positive theory of consumer choice, Journal of Economic Behavior \& Organization, vol. 1, issue 1.

Thaler R.H., 2000, From homo economicus to homo sapiens, Journal of Economic Perspectives, no. 14(1).

Thaler R.H., 2015, Misbehaving: The Making of Behavioral Economics, W.W. Norton \& Company, New York.

Veblen T., 1919, Why Is Economics Not an Evolutionary Science?, rep. in The Place of Science in Modern Civilization, New York.

Weintraub R.E., 2002, How economics became a mathematical science, Duke University Press, Durham.

Wittgenstein L., 1970, Traktat logiczno-filozoficzny, Państwowe Wydawnictwo Naukowe, 1970

Zboroń H., 2013, Dyskurs metodologiczny we współczesnej ekonomii-próba dekonstrukcji podejścia modernistycznego, Studia Ekonomiczne, nr 1 (LXXVI). 